\title{
Study on Reconstruction of English Translation Teaching Model in the Age of Big Data
}

\author{
Minfang Wang \\ Xijing University, Xi’an, Shaanxi 710100, China
}

Keywords: Big data; Translation teaching; Flipped classroom

\begin{abstract}
College English translation teaching is an important part of higher education in China. The effect of translation teaching is directly related to students' translation ability, foreign language application ability and the sustainable development of China's translation industry. In the context of the big data era, strengthening English translation teaching is very necessary. Combining traditional college English translation teaching with the advantages and potentials of data networks, can improve teaching quality and level, and enhance students' autonomous learning ability. This paper, starting from the problems faced by college English translation teaching in China, analyzes and combines the characteristics of the big data era, to explore the reconstruction of college English translation teaching mode under the background of big data era.
\end{abstract}

\section{Introduction}

Big data is a massive, high-growth, and diverse information asset that requires a new processing model to have greater decision-making, insight, and process optimization capabilities. In the context of big data, information technology can track and record all aspects of student online activities. We are no longer satisfied with knowing what it is, but deeply study causality. Innovative foreign language talents in the context of big data era should have good basic language skills, strong professional knowledge structure, innovative thinking ability and practical ability to analyze problems and solve problems. Under the leadership of big data technology, through information tracking and adjusting teaching strategies in a timely manner, teachers should strive to improve students' interest in learning and stimulate students' initiative. In this article, starting from the problems faced by college English translation teaching in China, we analyze and combine the characteristics of the big data era, to explore the reconstruction of college English translation teaching mode under the background of big data era.

\section{Disadvantages of Traditional English Translation Teaching}

Translation teaching can be broadly divided into two categories: professional translation teaching and college English translation teaching. The two classes of teaching have long been widely divergent. For ordinary colleges and universities, the road to college English translation teaching is still very long. After investigation, we found that there are still many problems in English translation teaching in colleges and universities in China.

\subsection{Backward English curriculum}

According to the "University English Course Teaching Requirements" issued by the Ministry of Education. Most colleges and universities offer English listening and speaking courses. Some of collages divide the traditional college English course into two parts, into English skills training and basis English, and a part of basis English is taught for listening training. By fully ensuring the training of listening and speaking ability, at the same time, in the teaching of basic English, emphasis is also on reading and writing, however, translation teaching has not received enough attention. In order to respond to the requirements of college English teaching reform, subject English is set up. The 
purpose of the course is to combine English learning with professional knowledge, but the focus of this course is still reading. Then enter the English expansion stage, and many English major courses have been set up for students to take electives. Currently, some colleges and universities have a higher awareness of curriculum, however, there are very few students taking elective courses, and teaching hours are also very few.

\subsection{Low level of translation teaching}

According to the author's usual observation and understanding, most English translation teaching in colleges and universities still uses traditional basic teaching. Many colleges and universities have not even opened a translation course for non-English majors. Translation teaching is not valued, in the teaching process, teachers merely takes translation as an auxiliary means of text comprehension or completes his practice. The teachers often ask someone to translate the text in class, or assign the task to the students after class to finish the comparison. They seldom or never mentioned translation theories and methods. Occasionally, some translation skills are involved in the process of text comprehension. On the other hand, high quality students are increasingly concentrated in well-known universities, and the English level of students in many local universities is generally poor, because most of these students come from poor areas. Under the joint action of both internal and external factors, it makes most students weak in translation. Students' lack of understanding of translation learning would affect students' English translation studies.

\subsection{Lack qualified teacher}

College English teachers are one of the most laborious groups of teachers in colleges and universities. With the continuous expansion of colleges and universities for many years, the number of students has increased dramatically, so a serious imbalance between teachers and students occur. Some college English classes are combined classes, even up to nearly 100 students. The characteristics of language teaching decide that the less class, the better, but the actual difficulties make it difficult for teachers to take care of every student, and teaching activities designed are also difficult to achieve the desired purpose. Meanwhile, in the field of translation teaching, there is few teachers with practical translation experience, most teachers don't understand translation theory. Due to the general lack of attention in colleges and universities, beyond heavy teaching tasks, teachers are reluctant to take extra time and focus on new teaching research.

\section{The Changes Brought by Big Data to English Translation Teaching}

\subsection{Changes in teaching resources}

In traditional English translation teaching, teachers rely on teaching materials to explain relevant knowledge and skills in class. While in big data era, there is no need to rely on textbooks and other means. On the one hand, many translation teaching resources on the Internet provide a large number of diverse guidance. On the other hand, corpora and powerful retrieval tools also provide effective help for business English translation teaching.

\subsection{Changes in teaching objectives}

One of the difficulties in traditional English translation teaching is the lack of purpose in student translation. Students often care more about form than content. In order to pursue the correctness of language expression, they often ignore the ideological content of the original content. In big data era, students can be both translators and readers. No longer just finishing homework, it can also be a new creation.

\subsection{Changes in teaching contents}

Network environment not only provides learners with abundant resources, but also provide a bridge for mutual communication, and such communication is an important way to produce content, because cooperation can help students generate more ideas and interests. This will not only help the 
translator to collect content, but also help the translator to think about the overall structure and layout of the article, so that ensure the logic and integrity of the translation.

\subsection{Changes in auxiliary means}

The network word processing system in the age of big data has greatly improved the efficiency of translation. Corpus, online search engines, and other computer software can help with vocabulary, grammar, and idiomatic usage. This greatly lightens the author's burden on language form, so that they can put more energy into content, and finally achieve the goal of effectively improving English translation ability.

\subsection{Changes in teaching evaluation}

In traditional translation teaching, all students' translations are corrected by teachers. On the one hand, the amount of information provided by teachers is limited; on the other hand, this way is not conducive to stimulating students' learning initiative. The big data era has changed this single assessment method. The evaluation of translation tasks is no longer confined to the evaluation of the teachers and the language forms of the evaluation subjects, but it depends on whether the translation result of the students reaches the communicative goal. For example, teachers can organize online discussions, and ask students express their views on a certain translation. Affirmed in peer evaluation would improve students' interest in learning. At the same time, the practice of peer evaluation has a positive impact on improving the appraiser's language ability and critical thinking ability.

\section{Translation Teaching Classroom Design Based on Big Data Technology}

\subsection{Lecture logic design}

English translation classroom design in the era of big data requires rigorous lecture logic design. Flipped classroom is not a simple process change, but is a rigorous logic system. Including the contents of teachers' responsibility and students' responsibility. In addition, flipped classroom also rely on big data technology to design a reliable comprehensive teaching platform. In many colleges, MOOC platform is utilized to provide good public class resources for students. If it is limited to teaching resources copyright, student information protection and other factors, educational administrators can also consider using data technology to design their own teaching platform. In a word, the design of teaching logic requires two aspects: preparation before class and classroom teaching, that is, to develop an objective and fair system of learning, communication and teamwork combined with the reality of English translation. The logic design system of translation teaching is shown in Figure 1.

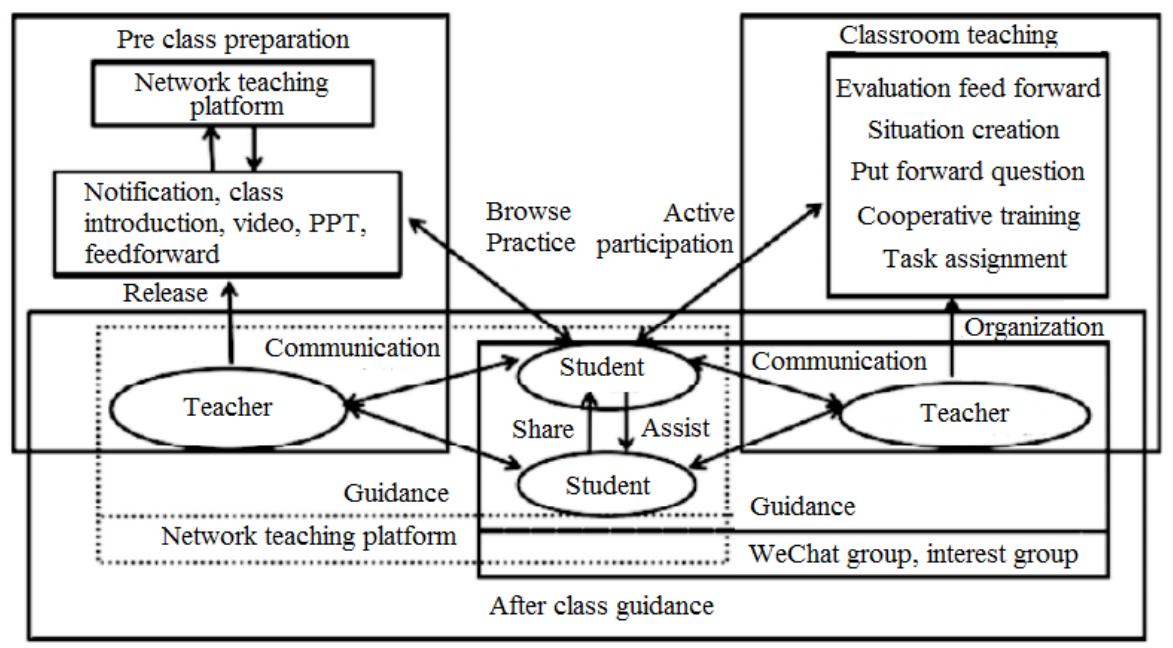

Figure 1. Logic design system of translation teaching 


\subsection{Pre-course material preparation}

Pre-course material preparation is an important basis for English translation and flipped classroom teaching, and also the core part of the whole teaching system. The difficulty in English translation lies in how to match the basic translation skills with the language, products, production system, laws, regulations and management rules needed in business activities. Taking English translation activities of financial institutions as example, teachers should use the basic terms of financial market mergers and acquisitions, commercial bank names, financial regulations, and securities insurance as the basic accumulation of translation skills in courseware, and make the appropriate application based on the selected case. Finally, use the platform database to set up after-school exercises, and summarize the common problems in student learning, for the improvement and supplement of post-courseware and teaching.

\subsection{Classroom design}

Big data-based flipped classroom teaching design needs to choose the appropriate teaching situation based on the specific situation of students' pre-learning. In classroom teaching, teachers select course cases based on these units. Based on the student's previous grades, to match the student's study group, agreed on the division of labor and translation content, and then inquire the professional reference books according to the collected questions, and analyze and solve problems in translation. Teachers can also guide students' translation activities as consultants, but the overall decision is in the hands of students.

\subsection{After class guidance}

In the after-school guidance session, within the teaching period, students can learn and cooperate in various ways, as well as seeking guidance from teachers. For example, building WeChat groups, interest groups, or use the learning platform for online collaboration. Improve the level of self-translation by various ways, for full exercise and practice. In the actual translation process, to understand and remember English translation knowledge, rather than rote learning theories.

\section{Innovation of English Translation Teaching Mode in the Era of Big Data}

\subsection{Clear translation teaching objectives}

In the teaching, apart from teaching basic translation theories and translation techniques, we also need to understand the demand for talent and specific job requirements in the social market. Teaching by combining reality would allow students to apply their knowledge to practical purposes, and the translation knowledge that they learn in school can be applied in the society. Our teaching aims at improving students' translation ability and practical ability. In view of insufficient course setting, some colleges and universities can be used as a reference, to set up some translation electives in the school, and thus provide students with a better learning platform. In addition, counselors can also encourage students to go to some foreign companies or foreign trade companies for internships, and allow students strengthen their translation knowledge through practice.

\subsection{Strengthen big data thinking}

In big data era, the role of the teacher has changed from evangelism to the transformation of the organizer and leader of learning. In the teaching, teachers need to cultivate big data thinking. Teachers need to keep up with the times, especially the education information technology abilities. Teachers need to learn how to use big data, and analyze and apply the data. Teachers can collect students' learning data in natural state, to understand these data in all dimensions. To find out the problems in the teaching process through the relationship between data, to forecast development trend and promote translation teaching. In translation teaching, teachers can make appropriate use of various network resources, such as search engine, online dictionary, translation software, corpus, to assist teaching. Some scholars believe that parallel corpora present sufficient and easy-to-screen 
bilingual data to students in classroom settings, to make translation skills and specific language project translation teaching relatively centralized. Moreover, with proper application, it helps to create high-quality autonomous learning and discovery teaching environment. Teachers can maintain more communication with students online, and receive timely feedback from students. They can also apply teaching software to send teaching materials to students' personal homepage in real time, so students can answer questions online and give feedback to teachers. Students can be encouraged to improve their translation ability by using big data, or learn to find out useful information from big data. In big data era, many WeChat public addresses on translation studies emerge, and information update is very fast. Students can take use of these resources to insist on extensive reading and translation exercises. All of these would help student improve their English translation level.

\subsection{Develop bilingual sensitivity of students}

In language teaching, language sensitivity can be understood as a special understanding of a language under certain knowledge. In translation activities, it involves the transformation of two languages. Therefore, teachers need to cultivate students' bilingual sensitivity. From the experience of self-translation teaching, some scholars find that they can cultivate students' sensitivity to bilingualism by emphasizing language aesthetics, integrating relevant theoretical knowledge, implementing the concept of text translation and using modern techniques. Combining the actual situation of the English translation learner group, these teaching methods can be used flexibly. We can browse resources extensively and watch excellent instructional videos.

\subsection{Update evaluation system}

The current situation of translation teaching is closely related to its traditional single assessment system. Teachers often give scores according to the answers, or are evaluated. In view of the fact that many students have weak English foundation, if the evaluation system is always rated by the score, it will defeat students' self-confidence and enthusiasm. We think that speech evaluation can be more applied, and rating can be used appropriately. In big data era, teachers can use a variety of evaluation methods in combination with the network platform. For example, organize students to use a variety of resources to complete small projects together, ask students score anonymously online, or let students share their translation experience. All of this can be included in the scope of the assessment. Teachers can also monitor and record the student's learning history through the online platform, master the learning situation at all stages of the student, so that grasp and assess the student's translation level as a whole.

\section{Conclusion}

The arrival of the era of big data is the result of the development of information technology network. All sectors are subject to their influence, and make use of its value and convenience. Combining traditional college English translation teaching with the advantages and potentials of data networks, can improve teaching quality and level, and enhance students' autonomous learning ability. At the time of the reform of college English teaching, to explore the changes brought by big data to college English translation teaching, and make full use of big data to give advantage to college English translation teaching, to help students develop good language skills, complete knowledge structure and ability to analyze and solve problems, so that improve the foreign language quality of college students as a whole.

\section{References}

[1] Zhao J Y, Zhen-Bo H U. Research on the Informative Teaching Mode of University under the Environment of Big Data[J]. Information Science, 2016.

[2] Liu H, University W D. Application of Micro-lesson in the Teaching of Translation Workshop during Big Data Age[J]. Journal of Xingtai Polytechnic College, 2015. 
[3] Zhu S M. The Research on Opportunities and Approaches of English Translation Teaching Based on Large Data[J]. Education Teaching Forum, 2018.

[4] Na Z. Research on the Flipped Classroom Teaching Mode of "Business Translation" Under the Background of Big Data[J]. Automation \& Instrumentation, 2017.

[5] Cheng W. Translation and Big Data Technology: Challenges and Implications[J]. Lebende Sprachen, 2017, 62(2).

[6] Cai Y, Department H. Exploration on the Construction of Digital Translation Teaching Resource Platform with Career-situation Leading[J]. Journal of Changchun University, 2014. 